\title{
Comparative study of the growth and carbon sequestration potential of Bermuda grass in industrial and urban areas
}

\author{
Usman Ali', Muhammad Azam Khan ${ }^{1 *}$, Ishfaq Ahmad Hafiz ${ }^{1}$, Khalid Saifullah Khan ${ }^{2}$ \\ and Shahid Mahmood ${ }^{3}$ \\ ${ }^{1}$ Department of Horticulture, Pir Mehr Ali Shah Arid Agriculture University Rawalpindi Pakistan \\ ${ }^{2}$ Institute of Soil Science, Pir Mehr Ali Shah Arid Agriculture University Rawalpindi Pakistan \\ ${ }^{3}$ Department of Environmental Sciences, Pir Mehr Ali Shah Arid Agriculture University Rawalpindi Pakistan
}

\begin{abstract}
Climate change is a global phenomenon occurring throughout the world. Greenhouse gases (GHGs) especially carbon dioxide $\left(\mathrm{CO}_{2}\right)$ considered to be the major culprit to bring these changes. So, carbon $(\mathrm{C})$ sequestration by any mean could be useful to reduce the $\mathrm{CO}_{2}$ level in atmosphere. Turf grasses have the ability to sequester $\mathrm{C}$ and minimize the effects of GHGs on the environment. In order to study that how turf grasses can help in C sequestration, Bermuda grass (Cynodon dactylon) was grown both at industrial and urban location and its effect on $C$ storage were assessed by soil and plant analysis. Dry deposition of ammonium and nitrate was maximum at both locations through the year. However wet deposition was highest during the months of high rainfall. It was examined through soil analysis that soil organic matter, soil $C$ and nitrogen in both locations increased after second mowing of grass. However, soil pH 6.68 in urban and 7.00 in industrial area and EC $1.86 \mathrm{dS} / \mathrm{m}$ in urban and $1.90 \mathrm{dS} / \mathrm{m}$ in industrial area decreased as the grass growth continue. Soil fresh weight $(27.6 \mathrm{~g})$ in urban and $(27.28 \mathrm{~g})$ industrial area also decreased after first and second mowing of grass. The C levels in plant dry biomass also increased which showed improved ability of plant to uptake $C$ from the soil and store it. Similarly, chlorophyll contents were more in industrial area compared to urban area indicates the positive impact of high $C$ concentration. Whereas stomatal conductance was reduced in high $C$ environment to slow down respiration process. Hence, from present study it can be concluded that the Bermuda grass could be grown in areas with high $C$ concentration in atmosphere for sequestrating $C$ in soil.
\end{abstract}

Keywords: Carbon sequestration, bermuda grass, nitrogen, soil, mowing, organic matter, EC

\section{Introduction}

Greenhouse gases (GHGs) emission in 250 years created the issue of global warming. Human activities, especially the excessive burning of fossil fuels such as coal, oil and gas have resulted in an excessive increase in atmospheric carbon dioxide $\left(\mathrm{CO}_{2}\right)$ level. (Bi et al., 2004). The impact of global warming triggered rise sealevel, higher frequency of fires in forests, climate change and occurrence of disasters (flooding and drought). High atmospheric $\mathrm{CO}_{2}$ might have also resulted in increment of absorption of $\mathrm{CO}_{2}$ by sea water, making the ocean more acidic, with potential disastrous impact on marine vegetation, fish, animals and coral reefs. Thus, technically and economically feasible strategies are needed to mitigate the consequences of increased atmospheric $\mathrm{CO}_{2}$ (Zhang et al. (2012).

Various strategies could be used to capture the $\mathrm{C}$ in oceans, soils, vegetation along with geologic formations for extended period of time. Although oceans store much of the $\mathrm{C}$ in atmosphere, soil also contributes about $75 \%$ of the $\mathrm{C}$ sink on land; almost three times more than the amount consumed and accommodated by living plants and animals. Therefore, soils have a major contribution in maintaining balanced global C cycle (Ecological Society of America, 2002). C storage depends on the ability of agricultural lands and forests to minimize $\mathrm{CO}_{2}$ from the atmosphere. Trees, plants and crops reduce $\mathrm{CO}_{2}$ by absorption through photosynthesis along with storage of carbon as biomass in various parts of tree and soil (EPA, 2008). Grasses are more unique than trees because they have an ability to store more $\mathrm{C}$ in the soil rather than in themselves unlike trees. When a fire comes, most $\mathrm{C}$ that has been stored in the soil stays there. But with trees, a fire that burns those trees release C into the atmosphere. Bermuda grass is the best turf grass which is used for $\mathrm{C}$ sequestration than the other agriculture plant/crops. Grasslands are called as C sinks because of their ability to store large amounts of $\mathrm{C}$ in them for longer periods of time. Land stores about $12 \%-29 \%$ of the overall soil C reserves (Eswaran et al., 1993). As C storage in ground is safer than plant parts, $\mathrm{C}$ storage in graze lands helps and can act as a long term proposed solution to

\footnotetext{
*Email: drazam1980@uaar.edu.pk
} 
decrease atmospheric $\mathrm{CO}_{2}$. Several factors result in enhanced soil $\mathrm{C}$ concentration in pastures as compared to agricultural lands, including thickening of roots, root exudation and minimum physical soil disturbance (Schuman et al., 2001).

Bermuda grass (Cynodon dactylon) is a hot season turf grass for lawns, parks, and sport fields. It is well distributed in arid, semi-arid, warm and humid areas (Shi et al., 2013). Turf grasses have the ability to sequester $\mathrm{C}$ and minimize the effects of GHGs on the environment. Thus present research was conducted to study the role of Bermuda grass on $\mathrm{C}$ sequestration by changing various physicochemical, physiological, mineralogical and ecological processes in soil. This study also aimed to assess the $\mathrm{C}$ sequestration in industrial and urban areas by the cultivation of Bermuda grass in different location and to estimate hidden anthropogenic $\mathrm{C}$ costs, related to the turf grass maintenance.

\section{Materials and Methods}

\section{Plant material}

Common Bermuda grass (Cynodan dactylon) was selected from two locations such as PMAS Arid Agriculture University lawn (Urban area) and Industrial area I-9 Islamabad-Pakistan. Existing Bermuda grass at both locations was managed through different practices (mowing, weeding and watering) to ensure uniform growth. In selected plots, planting of grass was done through sprigs and weeding, removing of insects, pests and irrigation was done according to crop demand. Urea (@ $20 \mathrm{~kg} / \mathrm{acre}$ ) was used as source of nitrogen on each plot to avoid damage to grasses. The study area was located at $33.6492^{\circ} \mathrm{N}, 73.0815^{\circ} \mathrm{E}$ (Urban area) and $33.6547^{\circ} \mathrm{N}, 73.0553^{\circ} \mathrm{E}$ (Industrial area). Each experiment was performed in triplicate.

\section{Determination of dry and wet deposition of ammonium and nitrate}

Wet deposition was monitored by installing rain gauges and dry deposition was configured by washing of tree leaves which was dip in water for few minutes and analyzed for ammonium and nitrate.

Rain water was collected every month (March 2016 to February 2017) in clean polythene bags with water collecting gauges installed at selected sites. The volume of rainwater was measured, and the water was analyzed calorimetrically to determine the ammonium-N and nitrate-N content (Keeney\& Nelson, 1987).

\section{Physicochemical characterization of soil}

Soil analysis was done to check the level of organic matter, nitrate- $\mathrm{N}$, ammonium- $\mathrm{N}$, total nitrogen $(\mathrm{N}), \mathrm{pH}$, $\mathrm{EC}$ and soil saturation percentage at 4 different growth stages. First sampling was done before planting grass, second after establishment of grass, third one month after first mowing, fourth after one month of $2^{\text {nd }}$ mowing.

Soil samples were analyzed by following procedures;

\section{Organic matter contents}

One gram air dried soil was weighed, then soil sample were transferred to $500 \mathrm{ml}$ conical flask, afterwards $5 \mathrm{ml}$ of $\mathrm{K}_{2} \mathrm{Cr}_{2} \mathrm{O}_{7}$ and mixed well. $10 \mathrm{ml}$ sulphuric acid was added and mixed. The flask was allowed to stand for 30 minutes to cool. Then 100-150 $\mathrm{ml}$ distilled water was added. $3 \mathrm{ml}$ phosphoric acid or $0.5 \mathrm{~g} \mathrm{NaF}$ was also added, 5-10 drops of indicator and it was finally be titrated against standardized ferrous sulphate to sharp green end point. In the end it runs blank and sample reading was subtracted from blank to get the actual volume of ferrous sulphate which was used to reduce potassium dichromate (Bhatti et al., 2013).

\section{Electrical Conductivity}

The electrical conductivity of soil was measured with EC meter (Model CrisonMM40+,Spain) (Bhatti et al., 2013).

\section{Carbon Percentage}

Determine the $\mathrm{C}$ Percentage out by multiplying organic matter with 0.05 (Kjeldahl, 1883).

$\mathrm{C} \%=$ Organic Matter (O.M) x 0.05

\section{Nitrogen percentage}

Percentage of nitrogen (N) was found out by dividing organic matter with 1.72 (Kjeldahl, 1883).

$\mathrm{N} \%=$ Organic Matter (O.M)/1.72

\section{Nitrate- $\mathrm{N}$ and Ammonium-N}

The extract was then analyzed by (Alpkem) continuous-flow colorimetry. Standard curve was drawn and results were compared with unknown samples. The calculations were done by following formula for nitrate$\mathrm{N}$ and Ammonium-N:

$\mu \mathrm{g}$ analyte per $\mathrm{g}$ dry soil $=(\mathrm{mg} / \mathrm{L}) X \frac{1000 \mu g}{1 \mathrm{mg} \text { soil }} \times \frac{0.021}{\text { dry weight } / \mathrm{gm})}$ 
The dry weight value of the soil sample was based on percent moisture data for each sample, obtained separately (Keeney\& Nelson, 1987).
pH 2013).

$\mathrm{pH}$ of soil was measured by $\mathrm{pH}$ meter (Bhatti et al.

Table 1: Wet and dry deposition of ammonium (mg kg $\left.{ }^{-1}\right)$ in soils of urban and industrial areas

\begin{tabular}{llllll}
\hline Month & Wet Deposition & & Dry Deposition & Mean \\
\cline { 2 - 6 } & Urban Area & Industrial Area & Urban Area & Industrial Area \\
\hline March 2016 & $0.31 \mathrm{qr}$ & $0.41 \mathrm{kl}$ & $0.28 \mathrm{~s}$ & $0.34 \mathrm{o}$ & $0.33 \mathrm{I}$ \\
April 2016 & $0.36 \mathrm{n}$ & $0.38 \mathrm{~m}$ & $0.33 \mathrm{p}$ & $0.36 \mathrm{n}$ & $0.35 \mathrm{H}$ \\
May 2016 & $0.30 \mathrm{r}$ & $0.32 \mathrm{q}$ & $0.26 \mathrm{t}$ & 0.401 & $0.32 \mathrm{~J}$ \\
June 2016 & $0.27 \mathrm{t}$ & $0.36 \mathrm{n}$ & $0.24 \mathrm{u}$ & $0.42 \mathrm{jk}$ & $0.32 \mathrm{~J}$ \\
July 2016 & $0.40 \mathrm{l}$ & $0.46 \mathrm{~h}$ & $0.34 \mathrm{op}$ & $0.38 \mathrm{~m}$ & $0.39 \mathrm{~F}$ \\
August 2016 & $0.44 \mathrm{i}$ & $0.51 \mathrm{f}$ & $0.38 \mathrm{~m}$ & $0.41 \mathrm{kl}$ & $0.43 \mathrm{D}$ \\
September 2016 & $0.42 \mathrm{j}$ & $0.46 \mathrm{~h}$ & $0.33 \mathrm{op}$ & $0.30 \mathrm{r}$ & $0.38 \mathrm{G}$ \\
October 2016 & $0.43 \mathrm{j}$ & $0.48 \mathrm{~g}$ & $0.38 \mathrm{~m}$ & $0.38 \mathrm{~m}$ & $0.42 \mathrm{E}$ \\
November 2016 & $0.53 \mathrm{e}$ & $0.54 \mathrm{de}$ & $0.41 \mathrm{kl}$ & $0.45 \mathrm{i}$ & $0.48 \mathrm{C}$ \\
December 2016 & $0.56 \mathrm{bc}$ & $0.59 \mathrm{a}$ & $0.43 \mathrm{j}$ & $0.49 \mathrm{~g}$ & $0.52 \mathrm{~A}$ \\
January 2017 & $0.49 \mathrm{~g}$ & $0.55 \mathrm{~cd}$ & $0.42 \mathrm{jk}$ & $0.51 \mathrm{f}$ & $0.49 \mathrm{~B}$ \\
February 2017 & $0.51 \mathrm{f}$ & $0.56 \mathrm{bc}$ & $0.45 \mathrm{i}$ & $0.57 \mathrm{~b}$ & $0.42 \mathrm{~B}$ \\
Mean & $0.42 \mathrm{~B}$ & $0.47 \mathrm{~A}$ & $0.35 \mathrm{C}$ & & $0.52 \mathrm{~A}$ \\
\hline
\end{tabular}

Means having same letter are not significantly different by the LSD at 0.05 probability level

Table 2: Wet and dry deposition of nitrate $\left(\mathrm{mg} \mathrm{kg}^{-1}\right)$ in urban and industrial areas

\begin{tabular}{|c|c|c|c|c|c|}
\hline \multirow[t]{2}{*}{ Month } & \multicolumn{2}{|c|}{ Wet Deposition } & \multicolumn{2}{|c|}{ Dry Deposition } & \multirow[t]{2}{*}{ Mean } \\
\hline & Urban Area & Industrial Area & Urban Area & Industrial Area & \\
\hline March 2016 & $0.42 \mathrm{yz}$ & $0.48 \times$ & $0.43 \mathrm{yz}$ & 0.62 op & $0.49 \mathrm{~J}$ \\
\hline April 2016 & $0.33 \mathrm{z}$ & $0.42 \mathrm{yz}$ & $0.47 \mathrm{x}$ & $0.58 \mathrm{rs}$ & $0.45 \mathrm{~K}$ \\
\hline May 2016 & $0.50 \mathrm{vw}$ & $0.59 \mathrm{qr}$ & $0.52 \mathrm{v}$ & $0.59 \mathrm{qr}$ & $0.55 \mathrm{H}$ \\
\hline June 2016 & $0.44 \mathrm{y}$ & $0.50 \mathrm{w}$ & $0.51 \mathrm{vw}$ & $0.58 \mathrm{rs}$ & $0.51 \mathrm{I}$ \\
\hline July 2016 & $0.55 \mathrm{tu}$ & $0.62 \mathrm{op}$ & $0.56 \mathrm{tu}$ & $0.65 \mathrm{jkl}$ & $0.60 \mathrm{G}$ \\
\hline August 2016 & $0.61 \mathrm{pq}$ & $0.65 \mathrm{jkl}$ & $0.64 \mathrm{lmn}$ & 0.66 hij & $0.64 \mathrm{E}$ \\
\hline September 2016 & $0.56 \mathrm{tu}$ & $0.61 \mathrm{pq}$ & 0.62 nop & $0.66 \mathrm{ijk}$ & $0.61 \mathrm{~F}$ \\
\hline October 2016 & $0.58 \mathrm{rs}$ & $0.64 \mathrm{klm}$ & $0.68 \mathrm{gh}$ & $0.71 \mathrm{de}$ & $0.65 \mathrm{D}$ \\
\hline November 2016 & $0.65 \mathrm{jkl}$ & 0.68 ghi & 0.70 ef & $0.81 \mathrm{a}$ & $0.71 \mathrm{~B}$ \\
\hline December 2016 & 0.62 op & 0.67 hij & 0.67 ghi & $0.76 \mathrm{bc}$ & $0.68 \mathrm{C}$ \\
\hline January 2017 & $0.63 \mathrm{mno}$ & $0.69 \mathrm{fg}$ & $0.76 \mathrm{c}$ & $0.80 \mathrm{a}$ & $0.72 \mathrm{~A}$ \\
\hline February 2017 & $0.55 \mathrm{u}$ & $0.57 \mathrm{st}$ & $0.72 \mathrm{~d}$ & $0.78 \mathrm{~b}$ & $0.65 \mathrm{D}$ \\
\hline Mean & $0.54 \mathrm{D}$ & $0.59 \mathrm{C}$ & $0.61 \mathrm{~B}$ & $0.68 \mathrm{~A}$ & \\
\hline
\end{tabular}

Means having same letter are not significantly different by the LSD at 0.05 probability level

Table 3: Effect of different growth stages of Bermuda grass on physicochemical characteristics of soil

\begin{tabular}{|c|c|c|c|c|c|c|c|c|}
\hline \multirow[b]{2}{*}{ Parameter } & \multicolumn{4}{|c|}{ Urban area } & \multicolumn{4}{|c|}{ Industrial area } \\
\hline & BP & GE & FM & SM & $\mathbf{B P}$ & GE & FM & $\mathbf{S M}$ \\
\hline Soil organic matter (\%) & $0.76 \mathrm{~d}$ & $0.80 \mathrm{c}$ & $0.86 \mathrm{~b}$ & $0.91 \mathrm{a}$ & $0.72 \mathrm{~d}$ & $0.75 \mathrm{c}$ & $0.79 \mathrm{~b}$ & $0.83 \mathrm{a}$ \\
\hline $\mathrm{EC}(\mathrm{dS} \mathrm{m}-1)$ & $1.99 \mathrm{a}$ & $1.96 \mathrm{ab}$ & $1.90 \mathrm{ab}$ & $1.86 \mathrm{~b}$ & $1.97 \mathrm{a}$ & $1.97 \mathrm{a}$ & $1.93 \mathrm{~b}$ & $1.90 \mathrm{~b}$ \\
\hline Carbon $(\%)$ & $0.44 \mathrm{~d}$ & $0.46 \mathrm{c}$ & $0.49 \mathrm{~b}$ & $0.53 \mathrm{a}$ & $0.41 \mathrm{~d}$ & $0.43 \mathrm{c}$ & $0.45 \mathrm{~b}$ & $0.48 \mathrm{a}$ \\
\hline Nitrogen $(\%)$ & $0.038 \mathrm{~d}$ & $0.040 \mathrm{c}$ & $0.043 \mathrm{~b}$ & $0.045 \mathrm{a}$ & $0.036 \mathrm{~d}$ & $0.037 \mathrm{c}$ & $0.039 \mathrm{~b}$ & $0.041 \mathrm{a}$ \\
\hline Nitrate N (mg kg-1) & $14.78 \mathrm{c}$ & $14.91 \mathrm{c}$ & $16.66 \mathrm{~b}$ & $18.52 \mathrm{a}$ & $14.79 \mathrm{~b}$ & $14.90 \mathrm{~b}$ & $16.74 \mathrm{a}$ & $17.86 \mathrm{a}$ \\
\hline $\begin{array}{l}\text { Ammonical-N } \\
(\mathrm{mg} \mathrm{kg}-1)\end{array}$ & $9.73 \mathrm{c}$ & $9.87 \mathrm{c}$ & $11.04 \mathrm{~b}$ & $11.97 \mathrm{a}$ & $9.75 \mathrm{c}$ & $9.82 \mathrm{c}$ & $11.19 \mathrm{~b}$ & $11.87 \mathrm{a}$ \\
\hline $\mathrm{pH}$ & $7.49 \mathrm{a}$ & $7.48 \mathrm{a}$ & $7.15 \mathrm{~b}$ & $6.68 c$ & $7.72 \mathrm{a}$ & $7.55 \mathrm{a}$ & $7.35 \mathrm{~b}$ & $7.00 \mathrm{c}$ \\
\hline Soil moisture (\%) & $70.33 \mathrm{c}$ & $70.40 \mathrm{c}$ & $74.66 \mathrm{~b}$ & $75.83 \mathrm{a}$ & $70.23 \mathrm{~b}$ & $70.36 \mathrm{~b}$ & $74.16 \mathrm{a}$ & $75.90 \mathrm{a}$ \\
\hline
\end{tabular}

$\mathrm{BP}=$ Before planting of grass, $\mathrm{GE}=$ After grass establishment, $\mathrm{FM}=$ First mowing, $\mathrm{SM}=$ Second mowing 


\section{Moisture percentage of soil}

For measuring soil moisture $10 \pm 0.01 \mathrm{~g}$ sub-samples of soil from each replicate was weighed into pre-weighed aluminum foil dishes and dried for $24 \mathrm{~h}$ at $105^{\circ} \mathrm{C}$ in a preheated oven, then it was cooled in desiccators. After drying, the dishes of dry soil was reweighed and the difference in weight was recorded to determine the moisture contents from the loss of mass, expressed on an oven dry weight basis (Riaz et al., 2008, Bhatti et al., 2013).

Mass of dry soil after incubation $=($ mass of soil + mass of dish) - mass of dish

Soil moisture percentage $=100$ (mass of water/mass of dry soil)

\section{Studying the physiological variation in Bermuda grass}

Chlorophyll content of plant was measured through chlorophyll meter (Riaz et al., 2008).

Grass samples were also analyzed for the leaf conductance by using a leaf porometer.

Electrolyte leakage was measured by using EC meter (Riaz et al., 2008).

\section{Fresh and Dry weight of above and below Ground Biomass}

First of all weight of thin brown paper bags were carefully found out by using weighing balance. Collected grass samples were kept in brown paper bags and weighed again. The weight of brown paper bag + fresh plant biomass was noted down. Weighed grass samples were kept in hot air oven for 24 hour for drying at $65 \circ \mathrm{C}$. Weight of dry plant biomass was found out by employing following formula:

Dry weight of grass shoots $=($ Dry Wt. of grass shoots with brown paper bags - Wt. of brown paper bags)

Dry weight of grass roots $=($ Dry Wt. of grass roots with brown paper bags - Wt. of brown paper bags).

\section{Carbon in dry Biomass (mg kg -1)}

The value of dry shoot and root was multiplied by the factor of 0.5 to obtain the value of $\mathrm{C}$ in dry biomass of grass Carbon in dry biomass $=($ dry weight of Roots + dry weight of Shoots) / 0.05 .

\section{Statistical analysis}

The data were analyzed by using the Analysis of Variance (ANOVA) to determine the differences in both locations and LSD was used for determining significant difference among the mean (Steel et al., 1997). Statistix 8.1 software was used for analyzing the data.

\section{Results}

\section{Dry and wet deposition of nitrogen compounds}

Wet and dry deposition of nitrogen compounds (ammonia and nitrate) at both locations during different months is shown in (Table $1 \& 2$ ). It was observed that dry deposition was more than wet deposition at both urban lawn area and industrial area. Nitrate deposition was more than ammonium deposition. In urban area during summer (March-June), wet deposition of nitrate was in a range of $0.33-0.55 \mathrm{mg} \mathrm{kg}^{-1}$ and dry deposition was $0.43-0.56 \mathrm{mg} \mathrm{kg}$ -1 . Similar in industrial area, where wet deposition was $0.42-0.62 \mathrm{mg} \mathrm{kg}^{-1}$ and dry deposition was $0.58-0.65 \mathrm{mg} \mathrm{kg}$ -1 . For ammonium, in urban area wet deposition ranges from $0.27-0.40 \mathrm{mg} \mathrm{kg}^{-1}$ and dry was $0.24-0.34 \mathrm{mg} \mathrm{kg}^{-1}$ and in industrial area, low wet $\left(0.32-0.46 \mathrm{mg} \mathrm{kg}^{-1}\right)$ and dry deposition (0.34-0.42 $\mathrm{mg} \mathrm{kg}^{-1}$ ) was observed. In JulySeptember period, heavy rainfall gives maximum value of ammonia and nitrate wet and dry deposition values. But as the winter approaches (October-January) deposition values increase significantly $(\mathrm{p}<0.05)$ at both location and gives highest values as compared to other months.

\section{Effect of different growth stages of Bermuda grass on soil parameters}

Data regarding effect of different growth stages of Bermuda grass on soil parameters is shown in Table 3. Results showed that different growth stages of Bermuda grass has positive effect on soil organic matter and it significantly changes at different growth stages. Minimum soil organic matter (\%) was determined at before planting stage in urban $(0.76 \%)$ and industrial location $(0.72 \%)$. Soil organic matter starts increasing after grass mowing and highest after second mowing of Bermuda grass and it was $0.91 \%$ at urban and $0.83 \%$ at industrial location. Similarly, soil C (\%) also changes with different growth stages of Bermuda grass, it was minimum before planting of Bermuda grass in both urban $(0.44 \%)$ and industrial area $(0.41 \%)$. However, after second mowing of Bermuda grass highest soil $\mathrm{C}$ percentage was examined at urban $(0.53 \%)$ and at industrial location $(0.48 \%)$. Soil nitrogen percentage (\%) decreases significantly before planting of grass. In urban growing area it was $0.036 \%$ and in industrial growing area it was $0.035 \%$. But when mowing of grass were started, it was maximum after second mowing in both urban $(0.045 \%)$ and industrial $(0.041 \%)$ growing area respectively. The amount of nitrogen compounds in Bermuda grass was significantly increased as the growth continuously enhanced. Level of nitrate $\left(\mathrm{mg} \mathrm{kg}^{-1}\right)$ and ammonium ( $\mathrm{mg} \mathrm{kg}^{-1}$ ) was minimum before planting of grass in urban (14.78 and $9.73 \mathrm{mg} \mathrm{kg}^{-1}$ ) and in industrial 
growing area (14.79 and $\left.9.75 \mathrm{mg} \mathrm{kg}^{-1}\right)$. However after second mowing of Bermuda grass, maximum value of nitrate $\left(\mathrm{mg} \mathrm{kg}^{-1}\right)$ and ammonium $\left(\mathrm{mg} \mathrm{kg}^{-1}\right)$ was observed at urban (18.52 and $\left.11.97 \mathrm{mg} \mathrm{kg}^{-1}\right)$ and industrial (17.86 and $11.87 \mathrm{mg} \mathrm{kg}^{-1}$ ) location. The soil moisture percentage changes at different growth stages of Bermuda grass, before planting of grass minimum soil percentage in urban $(70.3$ $\%)$ and in industrial $(70.2 \%)$ were recorded. But it starts increasing and after second mowing of grass it was maximum. After second mowing, soil moisture percentage was $75.8 \%$ in urban area and $75.9 \%$ in industrial area.

In contrast to these parameters, soil $\mathrm{pH}$ and $\mathrm{EC}$ significantly decreases with Bermuda grass growth. Highest EC value was observed before planting of grass in urban $\left(1.99 \mathrm{dS} \mathrm{m}^{-1}\right)$ and in industrial area $\left(1.97 \mathrm{dS} \mathrm{m}^{-1}\right)$. But after second mowing of Bermuda grass, EC value was significantly decreased in both urban (1.86 $\mathrm{dS} \mathrm{m}^{-1}$ ) and industrial $\left(1.90 \mathrm{dS} \mathrm{m}^{-1}\right)$ area. Similarly, soil $\mathrm{pH}$ at before grass planting and after grass establishment was same and it was alkaline. Soil pH before grass planting was 7.49 in urban and 7.72 in industrial area. After grass establishment stage, it was 7.5 at urban and 7.55 at industrial location. But after first and second mowing decrease in $\mathrm{pH}$ was observed and it was minimum after second mowing stage in urban (6.68) and industrial area (7.00). Soil fresh weight (g) also depicted the same trend and it was highest at before planting stage in urban and industrial location. In urban location, $33.61 \mathrm{~g}$ soil fresh weight was observed while it was $32.8 \mathrm{~g}$ at industrial location. However fresh weight starts decreasing after first moving and it was minimum after the second mowing of Bermuda grass. Lowest fresh weight was studied in urban (27.6 g) and industrial area $(27.28 \mathrm{~g})$ after second mowing.

\section{Effect of different $\mathrm{CO} 2$ levels in urban and industrial areas on plant parameters of Bermuda grass at different time intervals}

Effect of different $\mathrm{CO}_{2}$ levels in urban and industrial areas on plant parameters of Bermuda grass at different time intervals is presented in Table 4. Data related to chlorophyll content of Bermuda grass under environmental pollution showed the chlorophyll content increases as the growth continuous. Chlorophyll content was minimum at $\mathrm{T}_{1}$ time (10 days after grass establishment) in urban (36 SPAD readings) and industrial area location (40.6 SPAD readings). But as the grass continue its growth and development rate of chlorophyll content also increases. At $\mathrm{T}_{4}$ (75 days after grass establishment) highest chlorophyll contents were observed in leaves of Bermuda grass growing in urban area (52 SPAD readings) and industrial area (54.66 SPAD readings). Leaf conductance under high atmospheric $\mathrm{CO}_{2}$ changes significantly at different time interval. Minimum leaf conductance was observed in both urban $\left(0.36 \mathrm{~cm} \mathrm{~s}^{-1}\right)$ and industrial area $\left(0.33 \mathrm{~cm} \mathrm{~s}^{-1}\right)$ at $\mathrm{T}_{1}$ treatment (10 days after grass establishment). However, it increases with the time and maximum leaf conductance was examined in urban area $\left(0.50 \mathrm{~cm} \mathrm{~s}^{-1}\right)$ and in industrial are $\left(0.51 \mathrm{~cm} \mathrm{~s}^{-1}\right)$ at $\mathrm{T}_{4}$ treatment $(75$ days after grass establishment). Effect of different $\mathrm{CO}_{2}$ levels in urban and industrial areas on fresh and dry weight of above ground part (shoot) increased significantly. After 10 days of grass establishment, fresh weight of shoot was $2.75 \mathrm{~g}$ in urban and $2.78 \mathrm{~g}$ in industrial area. However, after 75 days of grass establishment as the grass grows older, shoot fresh weight was maximum. Shoot fresh weight was $7.9 \mathrm{~g}$ at both urban and industrial location. Similarly shoot dry weight was lowest at 10 days after grass establishment in urban (1.76 g) and industrial area (1.74 g) and highest value of shoot dry weight after 75 days of grass establishment was $4.06 \mathrm{~g}$ in urban and $3.92 \mathrm{~g}$ in industrial area. For fresh weight of below ground part (roots), Bermuda grass after 10 days of establishment yield minimum rate in urban $(1.53 \mathrm{~g})$ and in industrial area $(1.49 \mathrm{~g})$ but increases after 75 days of grass establishment in urban (3.94 g) and industrial area $(3.61 \mathrm{~g})$. Similar trend was observed for root dry weight, in which lowest value was observed in urban $(0.73 \mathrm{~g})$ and industrial area $(0.69 \mathrm{~g})$ after 10 days of establishment whereas it was highest at 75 days after grass establishment

Table 4: Effect of different $\mathrm{CO}_{2}$ levels in urban and industrial areas on physiological and morphological chracteristics of Bermuda grass in different time intervals

\begin{tabular}{|c|c|c|c|c|c|c|c|c|}
\hline \multirow[t]{2}{*}{ Parameter } & \multicolumn{4}{|c|}{ Urban area } & \multicolumn{4}{|c|}{ Industrial area } \\
\hline & T1 & T2 & T3 & T4 & T1 & T2 & T3 & T4 \\
\hline Chlorophyll content & $36 \mathrm{c}$ & $43.33 \mathrm{~b}$ & $49.33 \mathrm{a}$ & $52 \mathrm{a}$ & $40.66 \mathrm{c}$ & $46 \mathrm{~b}$ & $49 \mathrm{a}$ & $54.66 \mathrm{a}$ \\
\hline Leaf conductance $(\mathrm{cm} \mathrm{s}-1)$ & $0.36 \mathrm{~d}$ & $0.41 \mathrm{c}$ & $0.45 \mathrm{~b}$ & $0.50 \mathrm{a}$ & $0.33 \mathrm{~d}$ & $0.41 \mathrm{c}$ & $0.45 \mathrm{~b}$ & $0.51 \mathrm{a}$ \\
\hline Shoot fresh weight (g) & $2.75 \mathrm{~d}$ & $4.78 \mathrm{c}$ & $6.19 \mathrm{~b}$ & $7.99 \mathrm{a}$ & $2.78 \mathrm{~d}$ & $4.73 \mathrm{c}$ & $6.14 \mathrm{~b}$ & $7.9 \mathrm{a}$ \\
\hline Shoot oven dry weight (g) & $1.76 \mathrm{~d}$ & $2.42 \mathrm{c}$ & $3.12 \mathrm{~b}$ & $4.06 \mathrm{a}$ & $1.74 \mathrm{~d}$ & $2.40 \mathrm{c}$ & $2.94 \mathrm{~b}$ & $3.92 \mathrm{a}$ \\
\hline Root fresh weight $(\mathrm{g})$ & $1.53 \mathrm{~d}$ & $2.71 \mathrm{c}$ & $3.08 \mathrm{~b}$ & $3.94 \mathrm{a}$ & $1.49 \mathrm{~d}$ & $2.65 \mathrm{c}$ & $3.01 \mathrm{~b}$ & $3.61 \mathrm{a}$ \\
\hline Root oven dry weight (g) & $0.73 \mathrm{~d}$ & $1.34 \mathrm{c}$ & $1.52 \mathrm{~b}$ & $1.93 \mathrm{a}$ & $0.69 \mathrm{~d}$ & $1.29 \mathrm{c}$ & $1.47 \mathrm{~b}$ & $1.77 \mathrm{a}$ \\
\hline $\begin{array}{l}\text { Carbon in dry biomass ( } \mathrm{mg} \\
\mathrm{kg}-1)\end{array}$ & $50.07 \mathrm{~d}$ & $74 \mathrm{c}$ & $92.87 \mathrm{~b}$ & $119.87 \mathrm{a}$ & $42.73 \mathrm{~d}$ & $75.53 \mathrm{c}$ & $88.33 \mathrm{~b}$ & $112.6 \mathrm{a}$ \\
\hline
\end{tabular}


in urban $(1.93 \mathrm{~g})$ and industrial area $(1.77 \mathrm{~g})$. Analysis of data showed that $\mathrm{C}$ in dry biomass of Bermuda grass was minimum after 10 days of grass establishment. At urban location, $\mathrm{C}$ in dry biomass was $50.07 \mathrm{mg} \mathrm{kg}^{-1}$ whereas at industrial it was $42.73 \mathrm{mg} \mathrm{kg}^{-1}$. But after 75 days of grass establishment a significant increase in $\mathrm{C}$ in dry biomass was observed. It was $119.87 \mathrm{mg} \mathrm{kg}^{-1}$ in dry biomass of Bermuda grass growing in urban area whereas it was $112.6 \mathrm{mg} \mathrm{kg}^{-1}$ in dry matter of grass growing in industrial area

\section{Effect of different $\mathrm{CO} 2$ levels in urban and industrial areas on electrolyte leakage of Bermuda grass}

Electrolyte leakage of Bermuda grass under different $\mathrm{CO}_{2}$ levels in urban and industrial areas was measured in ionized and boiled deionized water. Results showed that electrolyte leakage was maximum in ionized water both in Bermuda grass leaves planted in urban area and in industrial area. In urban area, electrolyte leakage value in ionized water was $2.77 \mathrm{dS} \mathrm{m}^{-1}$ while in industrial area; it was slightly higher $\left(2.94 \mathrm{dS} \mathrm{m}^{-1}\right)$. However, in boiled deionized water, minimum electrolyte leakage was observed in urban $\left(2.19 \mathrm{dS} \mathrm{m}^{-1}\right)$ and industrial location (2.21 dS m $\left.{ }^{-1}\right)$ (Table 5).

Table 5: Effect of different $\mathrm{CO}_{2}$ levels in urban an industrial area on electrolyte leakage from Bermuda grass

\begin{tabular}{lll}
\hline & \multicolumn{2}{c}{ Electrolyte leakage (dS m-1) } \\
\cline { 2 - 3 } & Urban area & Industrial area \\
\hline IW & $2.77 \mathrm{a}$ & $2.19 \mathrm{a}$ \\
BW & $2.19 \mathrm{~b}$ & $2.21 \mathrm{~b}$ \\
\hline
\end{tabular}

\section{Discussion}

Statistical analysis showed that dry deposition of nitrate and ammonium was higher than wet deposition throughout the year because of drier surface that attract more pollutants due to electrostatic charges (Anderson et al., 2006). The nitrate and ammonia major source of emission is vehicle, exhaust, coal combustion, fertilizer manufacturing, industrial process and burning of biomass (Li et al., 2013; Sutton et al., 2014). So deposition of both compounds were highest in industrial location. Maximum wet deposition of ammonium and nitrate during high rainfall period obscured. Although lighter rain cleans the pollutants but heavy rainfall results in greater amount of deposit pollutants (Anderson et al., 2006). Significant increase of wet and dry deposition of nitrate was due to domestic heating, dry weather, low temperature and wind speed which led to more deposition of pollutants as these environmental condition does not allow the pollutants to transform into different compounds and diffuse ( $\mathrm{Li}$ et al., 2013). Ammonium deposition was lower than nitrate, ammonia in atmosphere reacts with sulfate and nitrate to form ammonium sulfate and ammonium nitrate aerosols which were transported $500 \mathrm{~km}$ from the source before they were removed from atmosphere through rain or dry deposition (Berner and Berner, 2012).

Results related to the effect of Bermuda grass on different soil parameters depict that increase in soil organic $\mathrm{C}$ after first and second mowing was due to addition of grass clippings to the soil. These grass clippings after decomposing increase the organic content of soil which increase the productivity of soil by providing available nutrients and improves the microbial activity (Tahar and Keltoum, 2011). Soil organic matter consists of dead plant, animal matter and microbial biomass that contain nutrients, minerals, $\mathrm{C}$ and $\mathrm{N}$ that is mineralized and added into the soil (Campbell, 2012; Law, 2014). From the results increase in soil $\mathrm{C}$ was caused by the fertilizer application and irrigation. Zirkle, (2010) reported that about 7-8\% dry biomass was produced in grass which is fertilized compared to unfertilized grass lawn. Through irrigation, an increase of $50.00-100.0 \mathrm{~kg} \mathrm{C} \mathrm{ha}^{-1} \mathrm{yr}^{-1}$ soil organic $\mathrm{C}$ was observed. Addition of mowed grass clippings into the soil and their decomposition increases the activity of soil microorganisms for 1-7 days and increase the storage of $\mathrm{C}$ up to 11-59\% (Canadell et al., 2007). It was observed from the statistical analysis that nitrogen content of soil increases after grass mowing which was due to the decomposition of plant residue in soil which increases the soil organic matter thus increases microbial activity which changes atmospheric nitrogen into usable form for the plants. Also, the addition of mowed grass clippings increases nitrogen concentration both in plants and in soil (Law, 2014).

Similarly, higher organic content in soil, increases the microbial activity which enhance the organic nitrogen mineralization through, decomposition of animal and plant matter, ammonification (conversion of nitrogen into ammonia through nitrogen fixing bacteria) and nitrification (conversion of ammonia to nitrate) thus increasing nitrate and ammonium level in soil (Ratsep, 1996; Plant et al., 2012). The application of nitrogenous fertilizer plays an important role in increasing nitrate and ammonium level in soil. In present result, ammonium level was lower than nitrate level because of nitrification process or uptake of ammonia by the growing plants from the soil (Kaiser et al., 2012). Presently Increase in fresh weight of soil at before planting stage was due to accumulation of various pollutants in soil that affects its organic matter and microbial growth which makes the soil compacted. Turf grasses improve the soil properties and its structure like soil aggregation, tilth, reduce erosion, increase water and nutrient retention and filter pollutants from the soil (Zarkile, 2010). This resulted into change of soil texture from 
compacted to loose form. As loose soil is lighter than compacted form so decrease in soil fresh weight at first and sowing mowing showed that soil was porous and well aerated as compared to compacted soil. After first and second mowing, grass clippings were added into soil as dead plant material which work as a mulch. As the mulch start decomposing, it increases the soil organic matter, reduce water loss and retain moisture. Decrease in soil $\mathrm{pH}$ after management practices (mowing) were due to the addition of organic matter in soil. As grass clippings decompose in soils it turns into organic matter which results in lowering of soil pH (Childers, 2006). EC (electrical conductivity) is a measurement of salt level. EC is correlated with $\mathrm{pH}$. As $\mathrm{pH}$ of soil decreases and at 6.8 range which means that soil has low level of salts accumulation. Also the increase in soil organic matter which prevents the movement of salt to the soil surface through evaporating water and increases the leaching down of salts from the root zone. Thus removing salts from the soil causes a decrease in soil EC value (Ramachandra, 2006).

Increase in chlorophyll content in industrial area improves the photosynthesis rate that causes an increase in assimilation of $\mathrm{CO}_{2}$ which ultimately resulted in increase in plant growth and production of biomass (Bhatt et al., 2010). Decrease in leaf conductance is one of the common responses of the plants under high atmospheric $\mathrm{CO}_{2}$ to reduce the transpiration loss (water loss) through stomata closing and opening (Lammerstma et al., 2011). However, as the grass growth continuous, leaf conductance increases because of increase in storage of $\mathrm{C}$ and nitrogen in plant and soil which ultimately increases the plant growth. As highest nitrogen value under atmospheric $\mathrm{CO}_{2}$ increases the leaf conductance. Although leaf conductance was reduced but it increases the photosynthesis rate and improves the plant water use efficiency (Karnosky, 2011).

Increase in fresh and dry weight of roots and shoots were due to lawn management practices such as mowing, fertilizer application (urea and DAP) and irrigation that increases the plant biomass by increasing the soil organic content which ultimately improves the nutrient availability and increases the plant growth (Zirkle, 2010). Increase in plant biomass in industrial area is also proved the adaptability of plant to the pollutant environment (Bhatt et al., 2010). An increase of $\mathrm{C}$ in dry biomass become older was due to the elevated atmospheric $\mathrm{CO}_{2}$ in industrial area which increases the photosynthetic rates that enhance the plant growth and development by increasing the $\mathrm{C}$ assimilation (Gautier, 2008). Increase in electrolyte leakage occurred due to stress conditions. Elevated atmospheric $\mathrm{CO}_{2}$ increases the acidification of cells, which increases the production of reactive oxygen species (ROS). These reactive oxygen species (ROS) alter different compositional and physical properties of cell membranes which results in change in lipid composition, separation of membrane phase and increase in leakage of electrolytes from the cell (Richardson, 2002; Omasa et al., 2012).

It was concluded from the results that Bermuda grass was effective in sequestrating of $\mathrm{C}$ and nitrogen in both soil and plants with the help of different management practices (irrigation, fertilizer application and mowing). Thus, this grass can be used as an environmental cleaner and can be grow in highly polluted areas.

\section{References}

Anderson, K. A. and J. A. Downing. 2006. Dry and wet atmospheric deposition of nitrogen, phosphorus and silicon in an agricultural region. Water Air and Soil Pollution 176 (1): 351- 374.

Berner, E. K. and R. A. Berner. 2012. Global Environment: Water, Air, and Geochemical Cycles. Princeton University Press.

Bhatt, R. K., M. J. Baig, H. S. Tiwari and S. Roy. 2010. Growth, yield and photosynthesis of Panicum maximum and Stylosanthes hamata under elevated $\mathrm{CO}_{2}$. Journal of Environmental Biology 31: 549-552.

Bhatti, H. N., S. Batool and N. Afzal. 2013. Production and characterization of a novel $\beta$-glucosidase from Fusarium solani. International Journal of Agriculture and Biology 15: $140-144$.

Bi, H., J. Turner and M. J. Lambert. 2004. Additive biomass equations for native eucalypt forest trees of temperate Australia. Trees 18:467-479.

Campbell, C. D. 2012. Soil carbon dynamics in lawns converted from Appalachian mixed oak stands. M.Sc. thesis, Virginia Polytechnic Institute and State University, Viriginia.

Canadell, J. G., D. E. Pataki and L. F. Pitelka. 2007. Terrestrial Ecosystems in a Changi World. Springer Science \& Business Media.

Childers, N. F. 2006. Blueberries for Growers, Gardeners, Promoters Norman F. Childers Horticultural Publications.

Ecology Society of America.2002. http://www.esa.org. EPA.2008. Carbon Sequestration in Agriculture and Forestry. www.epa.gov/sequestration/index.html

Eswaran, H., E. B. Vanden and P. Reich world. 1993. Soils science society of America Journal 57: 192-194.

Gautier, C. 2008. Oil, Water and Climate: An Introduction. Cambridge University Press.

Kaiser, D. R., D. J. Reinert, J. M. Reichert, C. A. Streck and A. Pellegrini. 2010. Nitrate and ammonium in soil solution in tobacco management systems. Revista Brasileira de Ciência do Solo 34(2): 379-388. 
Karnosky, D. 2001. The Impact of Carbon Dioxide and Other Greenhouse Gases on Forest Ecosystems: Report No. 3 of the IUFRO Task Force on Environmental Change (8). CABI.

Keeney, D. R. and D. W. Nelson. 1987. Inorganic forms of nitrogen. In A. L. Page (ed.). Methods of soil analysis. Agronomy, Volume 9, 2nd edition.

Kjeldahl, J. 1883. Neue Methode zur Bestimmung des Stickstoffs in organischen Körpern. Zeitschrift für analytische Chemie 22 (1): 366-383.

Lammertsma, E. I., H. J. de Boer, S. C. Dekker, D. L. Dilcher, A. F. Lotter and F. Wagner-Cremer. 2011. Global $\mathrm{CO}_{2}$ rise leads to reduced maximum stomatal conductance in Florida vegetation. Proceedings of the National Academy of Sciences 108 (10): 4035-4040.

Law, Q. D. 2014. Defining management strategies to maximize net soil carbon and nitrogen retention in turfgrass systems. M. Sc. thesis, Purdue university, Indiana.

Li, K., X. Liu, W. Song, Y. Chang, Y. Hu and C. Tian. 2013. Atmospheric nitrogen deposition at two sites in an arid environment of central Asia. PLOS one 8 (6): e67018.

Omasa, K., H. Saji, S. Youssefian and N. Kondo. (eds.). 2012. Air Pollution and Plant Biotechnology: Prospects for Phytomonitoring and Phytoremediation. Springer Science \& Business Media.

Plant, J. A., J. Bone, K. V. Ragnarsdottir and N. Voulvoulis. 2011. Pollutants, Human Health and the Environment-A Risk-Based Approach. John Wiley and Sons.

Ramachandra, T. V. 2006. Soil and Groundwater Pollution from Agricultural activities. The Energy and Resources Institute.

Ratsep, R. 1996. Biological Variables for Monitoring the Effects of Pollution in Small Catchment Areas: A Literature Survey. Nordic Council of Ministers.
Riaz, A., M. Arshad, A. Younis, A. Raza and M. Hameed. 2008. Effects of different growing media on growth and flowering of Zinnia elegans cv. Blue point. Pakistan Journal of Botany 40: 1579-1585.

Richardson, M. 2002. Environmental Xenobiotics. CRC Press. Schuman, G. E., J. E. Herrick and H. H. Janzen. 2001. The dynamics of soil carbon in rangeland. In the Potential of U.S. Grazing Lands to Sequester Carbon and Mitigate the Greenhouse Effect. ed. R.F. Follett, J.M. Kimble and R. Lal, 267-290. Boca Raton, Florida: Lewis Publishers.

Shi, H., T. Ye and Z. Chan. 2013. Exogenous application of hydrogen sulfide donor sodium hydrosulfide enhanced multiple abiotic stress tolerance in Bermuda grass (Cynodondactylon (L). Pers. Plant Physiology and Biochemistry 71: 226-234.

Sutton, M. A., K. E. Mason, L. J. Sheppard, H. Sverdrup, R. Haeuber and W. K. Hicks. (eds.). 2014. Nitrogen Deposition, Critical Loads and Biodiversity. Springer Science and Business Media.

Tahar, K. and B. Keltoum. 2011. Effects of heavy metals pollution in soil and plant in the industrial area, West Algeria. Journal of the Korean Chemical Society 55 (6): 1018- 1023.

Zirkle, G. N. 2010. Assessment of carbon sequestration in the US residential landscape. M.Sc. thesis, The Ohio State University, Columbus.

Zhang, C., H. Q. Tian, G. S. Chen, A. Chappelka, X. F. Xu, W. Ren, D. E. Hui, M. L. Liu, C. Q. Lu, S. F. Pan and G. Lockaby. 2012. Impacts of urbanization on carbon balance in terrestrial ecosystems of the Southern United States. Environmental Pollution 164, 89- 101. 